Matthew J. Barrett, MD, MSc

Eli S. Williams, $\mathrm{PhD}$

Chelsea Chambers, MS, CGC

Radhika Dhamija, MD

Neurol Genet

2017;3:e193; doi: 10.1212/ NXG.0000000000000193

Supplemental data at Neurology.org/ng

\section{AUTOSOMAL RECESSIVE INHERITANCE OF ADCY5-RELATED GENERALIZED DYSTONIA AND MYOCLONUS \\ OPEN}

Monoallelic ADCY5 mutations have been associated with a benign hereditary chorea-like phenotype and a mixed hyperkinetic syndrome with dystonia, chorea, and myoclonus. ${ }^{1-4}$ We report 2 siblings with generalized dystonia and myoclonus associated with biallelic pathogenic variants in ADCY5 inherited in an autosomal recessive pattern.

Case report. A 27-year-old woman presented with a movement disorder. She was born full term. She walked at 18 months, and speech development was delayed. Involuntary movements were first noted at 3 years with walking and increased in amplitude over time. Dystonia was first diagnosed at age 3. She had frequent falls due to involuntary myoclonic movements in the setting of lower extremity dystonia. Movements lessened with sleep and did not improve with alcohol or caffeine. Trihexyphenidyl, levodopa, clonazepam, and amantadine failed to provide benefit. On examination, she was found to have generalized dystonia with superimposed myoclonus. See video at Neurology.org/ng. Chromosomal microarray was negative. Alpha-fetoprotein and vitamin E levels were normal. Her 24-year-old brother was born at term and walked prior to 1 year. His speech development was delayed. After age 8, he developed cramping in his hands and neck. His gait worsened at age 15 secondary to worsening lower extremity dystonia following a growth spurt. Levodopa, clonazepam, gabapentin, propranolol, primidone, and topiramate did not provide benefit. His neurologic examination revealed generalized dystonia with superimposed myoclonus. See video. Creatine kinase, lactic acid, comprehensive metabolic panel, ceruloplasmin, and 24-hour urine copper levels were normal. No pathogenic variants or large deletions/ duplications were found in SGCE. Brain MRI was unremarkable. There were no other siblings. Neither parent nor other relatives had a history of a movement disorder.

Because of familial juvenile-onset generalized dystonia with myoclonus and previous negative evaluations, trio exome sequencing was pursued to establish a definitive diagnosis (Ambry Genetics Corp., Aliso Viejo, CA). Testing revealed the presence of a maternally inherited frameshift variant (c.409_428del20; p.G137Cfs*184) and a paternally inherited missense variant (c.3037C $>$ T; p.R1013C) in ADCY5 (NM_183357). These alleles were confirmed in the proband's brother using Sanger sequencing.

Discussion. ADCY5 mutations are believed to be inherited in an autosomal dominant fashion based on observations from the original pedigree: there were affected individuals in all 5 generations, complete penetrance in males and females, and evidence of male-to-male transmission. ${ }^{5}$ Subsequent reported families confirmed autosomal dominant inheritance. ${ }^{3,4}$ In addition, mutations described in ADCY5related dyskinesia are recurrent, with the p.R418W and the p.A726T mutation described in multiple unrelated individuals. ${ }^{1-3,6}$ Subsequent functional analysis characterized the effect of these mutations as gain of function: there was increased adenylyl cyclase activity in cells containing mutant $A D C Y 5$ compared with wild type. ${ }^{6}$ However, in a previously reported family affected with autosomal dominant chorea and dystonia, a c. $2088+1 \mathrm{G}>\mathrm{A}$ splice site mutation segregated with disease. ${ }^{4}$ Functional studies showed no expression of the variant allele and reduced expression of $A D C Y 5$ messenger RNA. It appears that both gain of function and haploinsufficiency may result in ADCY5-related dyskinesia.

Here, we report 2 siblings with a phenotype of generalized dystonia and myoclonus associated with biallelic pathogenic variants in $A D C Y 5$. A phenotype of autosomal dominant myoclonus dystonia has been reported with $A D C Y 5$ mutations, and dystonia and myoclonus have been reported in other published cases. $^{7}$ Our cases differ from previously published cases because they inherited 2 pathogenic variants from unaffected parents, a paternally inherited missense variant and a maternally inherited frameshift variant. There is evidence supporting a role for both these variants in the clinical manifestation of disease. The paternal p.R1013C variant occurs at an evolutionarily conserved residue, is predicted to be damaging by PolyPhen and deleterious by scale-invariant 
feature transform, and is not present in over 60,000 individuals in the Exome Aggregation Consortium browser. These data together with cosegregation with the movement disorder phenotype suggest that p.R1013C is not a normal population variant and has clinical significance. We interpret the maternally inherited 20 base-pair deletion as a loss of function allele because it results in an early stop codon after 184 amino acids.

In this family, both variants appear to be required for a movement disorder phenotype. The missense variant may result in a change in the function of adenylate cyclase that does not result in a phenotype in the presence of a wildtype allele. However, in the presence of a null allele, the mutant protein is insufficient to maintain adequate cyclic adenosine monophosphate levels resulting in dystonia and myoclonus. Autosomal recessive inheritance has also been reported for other genes typically associated with autosomal dominantly inherited dystonia, specifically THAP1 and $G N A L{ }^{8,9}$ This family expands the understanding of $A D C Y 5$-related dyskinesia by showing that certain pathogenic variants inherited in an autosomal recessive pattern may produce a phenotype identical to autosomal dominant mutations.

From the Department of Neurology (M.J.B., C.C.), and Department of Pathology (E.S.W.), University of Virginia Health System, Charlottesville; and Department of Clinical Genomics and Neurology (R.D.), Mayo Clinic, Phoenix, AZ.

Author contributions: Dr. Barrett: drafting the original manuscript and analysis and interpretation of data. Dr. Williams, Ms. Chambers, and Dr. Dhamija: analysis and interpretation of data and revising the manuscript for intellectual content.

Study funding: No targeted funding reported.

Disclosure: M.J. Barrett has received research support from Axovant Sciences Inc., Azevan Pharmaceuticals, and Merck Sharp \& Dohme Corp. and receives support from the Commonwealth of Virginia's Alzheimer's and Related Diseases Research Award Fund and the Office of the Assistant Secretary of Defense for Health Affairs through the Neurotoxin Exposure Treatment Parkinson's Research Program. E.S. Williams has served on the editorial board of Current Genetic Medicine Reports. C. Chambers and R. Dhamija report no disclosures. Go to Neurology.orging for full disclosure forms. The Article Processing Charge was funded by the authors.

This is an open access article distributed under the terms of the Creative Commons Attribution-NonCommercial-NoDerivatives $L i$ cense 4.0 (CC BY-NC-ND), which permits downloading and sharing the work provided it is properly cited. The work cannot be changed in any way or used commercially without permission from the journal.

Received February 22, 2017. Accepted in final form August 15, 2017.

Correspondence to Dr. Barrett: mjbarrett@virginia.edu

1. Chen DH, Meneret A, Friedman JR, et al. ADCY5-related dyskinesia: broader spectrum and genotype-phenotype correlations. Neurology 2015;85:2026-2035.

2. Mencacci NE, Erro R, Wiethoff S, et al. ADCY5 mutations are another cause of benign hereditary chorea. Neurology 2015;85:80-88.

3. Chang FC, Westenberger A, Dale RC, et al. Phenotypic insights into ADCY5-associated disease. Mov Disord 2016;31:1033-1040.

4. Carapito R, Paul N, Untrau M, et al. A de novo ADCY5 mutation causes early-onset autosomal dominant chorea and dystonia. Mov Disord 2015;30:423-427.

5. Chen YZ, Matsushita MM, Robertson P, et al. Autosomal dominant familial dyskinesia and facial myokymia: single exome sequencing identifies a mutation in adenylyl cyclase 5. Arch Neurol 2012;69:630-635.

6. Chen YZ, Friedman JR, Chen DH, et al. Gain-of-function ADCY5 mutations in familial dyskinesia with facial myokymia. Ann Neurol 2014;75:542-549.

7. Douglas AG, Andreoletti G, Talbot K, et al. ADCY5related dyskinesia presenting as familial myoclonus-dystonia. Neurogenetics 2017;18:111-117.

8. Schneider SA, Ramirez A, Shafiee K, et al. Homozygous THAP1 mutations as cause of early-onset generalized dystonia. Mov Disord 2011;26:858-861.

9. Masuho I, Fang M, Geng C, et al. Homozygous GNAL mutation associated with familial childhood-onset generalized dystonia. Neurol Genet 2016;2:e78. doi: 10.1212/ NXG.0000000000000078. 


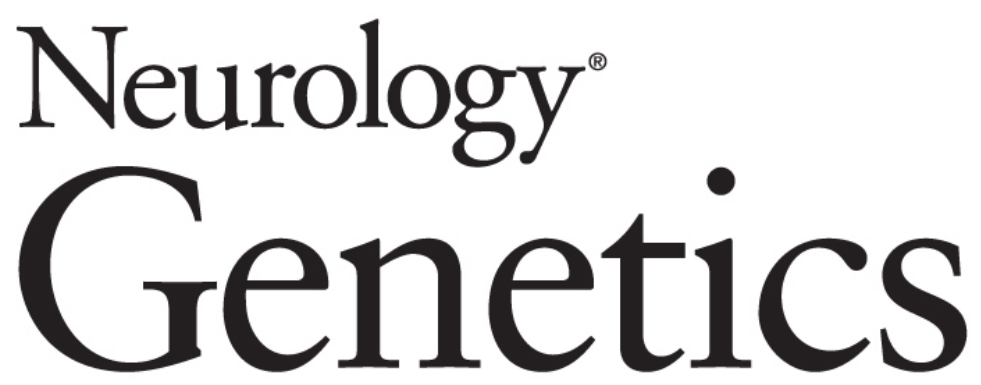

Autosomal recessive inheritance of $A D C Y 5$-related generalized dystonia and myoclonus Matthew J. Barrett, Eli S. Williams, Chelsea Chambers, et al. Neurol Genet 2017;3;

DOI 10.1212/NXG.0000000000000193

This information is current as of September 25, 2017

Neurol Genet is an official journal of the American Academy of Neurology. Published since April 2015, it is an open-access, online-only, continuous publication journal. Copyright Copyright $\odot 2017$ The Author(s). Published by Wolters Kluwer Health, Inc. on behalf of the American Academy of Neurology.. All rights reserved. Online ISSN: 2376-7839.

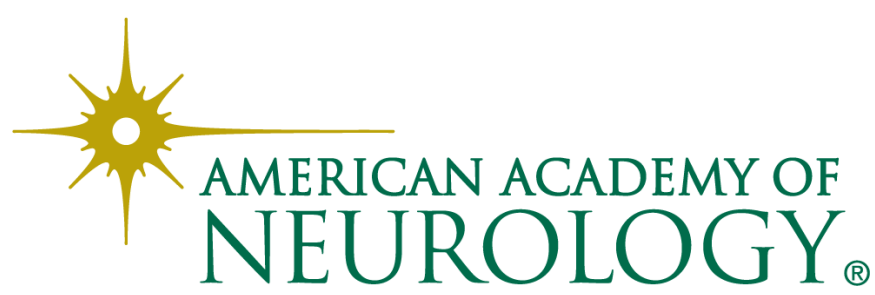




\section{Updated Information \& Services}

\section{Supplementary Material}

\section{References}

Citations

Subspecialty Collections

Permissions \& Licensing

Reprints including high resolution figures, can be found at: http://ng.neurology.org/content/3/5/193.full.html

Supplementary material can be found at: http://ng.neurology.org/content/suppl/2017/09/25/3.5.193.DC1

This article cites 9 articles, 1 of which you can access for free at: http://ng.neurology.org/content/3/5/193.full.html\#\#ref-list-1

This article has been cited by 3 HighWire-hosted articles: http://ng.neurology.org/content/3/5/193.full.html\#\#otherarticles

This article, along with others on similar topics, appears in the following collection(s):

\section{All Genetics}

http://ng.neurology.org//cgi/collection/all_genetics

All Movement Disorders

http://ng.neurology.org//cgi/collection/all_movement_disorders

All Pediatric

http://ng.neurology.org//cgi/collection/all_pediatric

Dystonia

http://ng.neurology.org//cgi/collection/dystonia

Myoclonus

http://ng.neurology.org//cgi/collection/myoclonus

Information about reproducing this article in parts (figures,tables) or in its entirety can be found online at:

http://ng.neurology.org/misc/about.xhtml\#permissions

Information about ordering reprints can be found online:

http://ng.neurology.org/misc/addir.xhtml\#reprintsus

Neurol Genet is an official journal of the American Academy of Neurology. Published since April 2015, it is an open-access, online-only, continuous publication journal. Copyright Copyright ( 2017 The Author(s). Published by Wolters Kluwer Health, Inc. on behalf of the American Academy of Neurology.. All rights reserved. Online ISSN: 2376-7839.

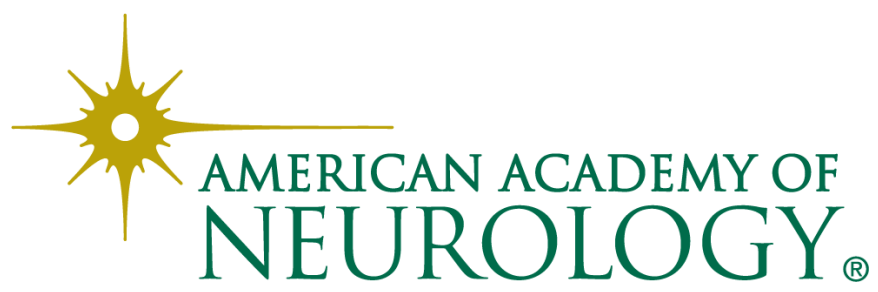

